\title{
Polymorphisms in autophagy genes and active pulmonary tuberculosis susceptibility in Romania
}

\section{Polimorfisme ale genelor autofagiei și susceptibilitatea la tuberculoză în România}

Mihai Gabriel Cucu ${ }^{1, \#}$, Ioana Streaţa ${ }^{1, \#}$, Anca Lelia Riza ${ }^{1, \#}$, Alina Liliana Cimpoeru $^{1}$, Simona Șerban-Șoșoi ${ }^{1}$, Adela Ciocoiu ${ }^{1}$, Răzvan Mihail Pleșea ${ }^{1}$, Elena Leocadia Popescu ${ }^{1}$, Ștefania Dorobanțu ${ }^{1}$, Andreea Anghel ${ }^{1}$, Aida Maria Stroe ${ }^{1}$, Andreea Nicoleta Ștefan ${ }^{1}$, Ramona Cioboată², Ileana Băzăvan², Marius Sorin Ciontea $^{3}$, Iulia Căpitănescu ${ }^{3}$, Mihai Olteanu ${ }^{2}$, Mimi Niţu ${ }^{2}$, Florin Burada ${ }^{1}$, Tiberiu Tătaru ${ }^{4}$, Mihai Netea ${ }^{5}$, Reinout van $\mathrm{Crevel}^{5}$, Marian Olaru ${ }^{2, \#}$, Francisc Mixich ${ }^{1, \#,}$ Mihai Ioana ${ }^{1, \#, *}$

${ }^{1}$ University of Medicine And Pharmacy Craiova, Dolj County, Romania,

2 "Victor Babes" Infectious Diseases and Pneumophtisiology Hospital Craiova, Dolj County, Romania,

3 "Tudor Vladimirescu” Pneumophtisiology Hospital Runcu, Gorj County, Romania,

${ }^{4}$ Emergency County Hospital Targu Jiu, Romania,

${ }^{5}$ Department of Internal Medicine and Radboud Center for Infectious Diseases (RCI), Radboud University Medical Center, Nijmegen, The Netherlands

\begin{abstract}
Autophagy, a homeostatic process involved in nutrient regeneration and immune responses, may be involved in intracellular killing of M. tuberculosis. Several studies linked variation in autophagy genes with susceptibility to pulmonary tuberculosis, but others did not confirm these findings.

We genotyped single nucleotide polymorphisms (SNPS) in the ATG5 (rs2245214, c.574-12777G>C) and NOD2 (rs2066844, c.2104C>T) genes for 256 pulmonary tuberculosis patients and 330 unrelated healthy controls in Romania. Both SNPs have been reported as relevant for the autophagy process and potentially for susceptibility to active pulmonary tuberculosis.

In our study, the polymorphisms in ATG5 and NOD2 were not associated with tuberculosis. This suggests that the two genetic variants we focused on are not related to the risk for developing active TB in a Romanian population.

Keywords: tuberculosis, gene polymorphism, autophagy, innate immune system, allele.
\end{abstract}

* Corresponding author: Mihai Ioana, University of Medicine And Pharmacy Craiova, Dolj County, Romania, e-mail: mihaiioana_romania@yahoo.com

\#These authors contributed equally to this work 


\section{Rezumat}

Autofagia, un proces homeostatic implicat în regenerarea nutrienților și a răspunsului imun, poate fi implicată în distrugerea intracelulară a M. tuberculosis. Unele studii au făcut legătura dintre unele variații în genele autofagiei și susceptibilitatea la tuberculoză, în timp ce alte studii nu confirmă acest lucru.

Am genotipat polimorfisme mononucleotidice (SNP) pentru genele ATG5 (rs2245214, c.574-12777G>C) și NOD2 (rs2066844, c.2104C>T) pentru 256 pacienți cu tuberculoză pulmonară și 330 subiecți sănătoși neînrudiți, în România. Ambele polimorfisme au fost raportate ca având relevanță pentru procesul de autofagie și potențial pentru susceptbilitatea pentru tuberculoză pulmonară activă.

În studiul nostru, polimorfismele genelor ATG5 și NOD2 nu au fost asociate cu tuberculoza. Acest fapt sugerează că cele două variante genetice pe care ne-am axat nu sunt legate de riscul de a dezvolta TB activă într-o populație românească.

Cuvinte cheie: tuberculoza, polimorfism, autofagie, sistem imun înnăscut, alele.

Received: $12^{\text {th }}$ July 2016 ; Accepted:12 ${ }^{\text {th }}$ December 2016 ; Published: $8^{\text {th }}$ January 2017.

\section{Introduction}

Pulmonary tuberculosis (TB), caused by infection with the bacillus Mycobacterium tuberculosis (Mtb), is the leading cause of death from infectious disease worldwide. World Health Organization reported more than 9.6 million new TB cases for 2014 and 1.5 million patients died due to this severe infection the same year. Mtb is transmitted between individuals mainly by aerosol droplets generated by patients with active pulmonary disease and is able to invade, persist and replicate inside macrophages by arresting phagosome maturation and inhibiting phagosome-lysosome fusion. Macrophages can control this evasion by inducing autophagy, an elaborate cellular process through which cytoplasmic contents that also include the bacilli, are targeted for lysososmal degradation, thus decreasing the bacterial burden within infected cells.

Autophagy is conserved during evolution, mediating the degradation of deficient organelles or proteins during stress or starvation conditions, allowing the eukaryotic cell to generate the necessary nutrients. It has been revealed that autophagy also modulates inflammation within the innate immune system, as well as adaptive immune responses. Autophagy works by forming a double membrane structure called autophagosome which sequestrates cytosolic material and later merges with the lysosome to degrade and afterwards release the resulted products back to the cytosol. This process is regulated by a specific set of genes from the autophagy-related family of genes (ATGs). Once the autophagy process is induced, different components of the autophagy pathway, such as ATG5, ATG12, ATG16 and LC3, cooperate to form the autophagosomes and deliver the sequestrated material to the lysosome. ATG5 is a central regulator gene in the process of autophagy, being involved in the elongation of the autophagosome membrane. In addition, NOD2 (CARD15 or NLRC2) is an important member of the NLR family expressed in macrophages, granulocytes and monocytes, which recognizes both Gram-positive and Gramnegative bacteria and has been showed to control the autophagy process. A clear involvement of NOD2 in recognition of Mtb has been shown in NOD2-/- mice. On the other hand, the role of autophagy for anti-mycobacterial host defense has been challenged, by a recent study that while confirming that ATG5 has an important role in the host response to mycobacterial infection by restricting Mtb growth, it brought into question the role of autophagy in this process.

To investigate the role of autophagy for host defense against tuberculosis in humans, we hypothesized that genetic variants such as 
the single nucleotide polymorphisms (SNPs) in the ATG5 - rs2245214 (c.574-12777G $>$ C) and NOD2- rs2066844 (c.2104C >T) genes is associated with susceptibility to active TB.

\section{Material and Method}

We genotyped ATG5 rs2245214 and NOD2 rs2066844 SNPs in 256 unrelated Romanian patients with active or history of pulmonary TB (81.3\% men, mean age 50.9 years) and in 330 gender- and age- matched healthy unrelated Romanian subjects $(57.3 \%$ men, mean age 60.7 years) with no positive history of tuberculosis. Of note, the male to female ratio in the TB group is a common finding in epidemiological studies.

The subjects were enrolled during 2011-2013 in Gorj and Dolj, South-Western Romania, two of the counties with high TB incidence in Romania.

Active TB diagnosis was based on clinical, radiological and laboratory results (sputum microscopy and culture), according to National Standards as recommended by the National Programme for Tuberculosis Control. Sputum microscopy was performed with Ziehl-Neelsen staining, without prior concentration of the sample. Culturing was performed on Loewenstein Jensen solid media. Definite diagnosis was based on culture positivity. Clinical and pulmonary chest X-ray findings supported the diagnosis.

History of TB was mainly interview-based. Although hospital records were queried to confirm subject declared data, there are limitations to how extensive the databases are. Nonetheless, there were no discrepancies identified.

The control group was screened for active TB using a symptom screen and a pulmonary chest X-ray. Romania is in a highly endemic region, with possible high background latency. Latency testing is not routinely recommended by national guidelines in adults and has not been performed for the purposes of this study.

Ethical approval for this study was obtained from the Ethics Committee of the University of Medicine and Pharmacy from Craiova, Romania, and all the tested subjects provided written informed consent.

Detection of the allelic variants was performed on genomic DNA isolated and purified from peripheral venous blood samples collected on EDTA using TaqMan assays (C_3001905_20, C_11717468_20, Applied Biosystems, Foster City, CA) designed to detect the the rs2245214 and rs2066844 SNPs. The methodology and cycling protocol are similar to those used to detect other SNP allelic variants.

Assessment of the Hardy-Weinberg equilibrium was performed with online software available at http://www.had2know.com/academics/ hardy-weinberg-equilibrium-calculator-2-alleles.html. Statistical analysis of the allelic variants and genotypes frequency was performed using GraphPad Prism, version 6.01 for Windows (GraphPad Software, La Jolla California, USA). Associations between genotypes and TB were calculated as odds ratios (OR) with $95 \%$ confidence intervals, based on the dominant and recessive models.

\section{Results and Discussion}

ATG5 rs2245214 (c.574-12777G >C) and NOD2 rs2066844 (c.2104C >T) genotype results for the TB and the control group are summarized in Table 1. To our knowledge, this is a first report of the single nucleotide polymorphisms (SNPs) in the Romanian population.

Frequency for the minor allele $(\mathrm{G})$ for the intronic rs 2245214 was comparable between the TB group (33.01\%) and the control group (33.38\%). The reported frequency seems to be similar with the European population (AFR 53\%, AMR 50\%, ASN 47\%, EUR 36\%, based on the 1000 genomes study, using the HaploReg v4.1 online at http:// archive.broadinstitute.org/mammals/haploreg/ haploreg.php, accessed at 31/10/2016). 
Table 1. Genotype frequency for ATG5 rs2245214 (c.574$12777 \mathrm{G}>\mathrm{C})$ and NOD2 rs2066844 (c.2104C $>$ T)

\begin{tabular}{lll}
\hline \multicolumn{3}{l}{ ATG5 rs2245214 (c.574-12777G>C) } \\
\hline Genotype & TB (\%, n) & Control (\%, n) \\
\hline CC & $20.83 \%, 121$ & $25.99 \%, 151$ \\
\hline CG & $17.83 \%, 101$ & $22.55 \%, 131$ \\
\hline GG & $5.85 \%, 34$ & $7.4 \%, 43$ \\
\hline
\end{tabular}

\begin{tabular}{lll}
\hline \multicolumn{3}{l}{ NOD2 rs2066844 (c.2104C $>$ T) } \\
\hline Genotype & TB (\%, n) & Control $(\%, \mathbf{n})$ \\
\hline CC & $40.96 \%, 240$ & $52.39 \%, 307$ \\
\hline CT & $2.73 \%, 16$ & $3.75 \%, 22$ \\
\hline TT & 0 & $0.17 \%, 1$ \\
\hline
\end{tabular}

\section{Dominant model}

OR $0.9956, \mathrm{p}=0.9858$

\section{Recessive model}

OR $1.0328, \mathrm{p}=0.8471$

\section{Dominant model}

OR 2.3354, $\mathrm{p}=0.6040$

\section{Recessive model}

OR $1.1238, \mathrm{p}=0.7289$

Table 2. Hardy-Weinberg equilibrium for ATG5 rs2245214 (c.574$12777 \mathrm{G}>\mathrm{C})$ and NOD2 rs2066844 (c.2104C $>$ T)

\begin{tabular}{lll}
\hline \multicolumn{3}{l}{ ATG5 rs2245214 (c.574-12777G $>$ C) } \\
\hline Genotype & Observed & Expected \\
\hline CC & 121 & 114.89 \\
\hline CG & 101 & 113.22 \\
\hline GG & 34 & 27.89 \\
\hline $\mathbf{p}=\mathbf{0 . 0 8 4 3}$ & & \\
\hline
\end{tabular}

Frequency for the minor allele (T) for the missense rs 2066844 was $3.13 \%$ in the TB group and $3.64 \%$ in the control group, again comparable with European reported frequencies (AFR 0\%, AMR 3\%, ASN 0\%, EUR 5\%, using HaploReg v4.1).

Our findings did not reach significance for the two studied SNPs, ATG5 rs2245214 (c.574$12777 \mathrm{G}>\mathrm{C}$ ) and NOD2 rs2066844 (c.2104C > T), under both the dominant and the recessive model of association between a genotype and a phenotype (see Table 1).

The frequencies of ATG5 rs2245214 (c.574$12777 \mathrm{G}>\mathrm{C}$ ) and NOD2 rs2066844 (c.2104C > T) genotypic variants in patients diagnosed with active TB or with known history of mycobacterial infection did not differ from those of the healthy individuals as seen above (Figure 1). The fre-

\begin{tabular}{lll}
\hline NOD2 & rs2066844 $(\mathbf{c} .2104 C>$ T) \\
\hline Genotype & Observed & Expected \\
\hline CC & 240 & 240.25 \\
\hline CT & 16 & 15.5 \\
\hline TT & 0 & 0.25 \\
\hline $\mathbf{p}=\mathbf{0 . 6 0 5 8}$ & & \\
\hline
\end{tabular}

quencies of both genetic polymorphisms in the two groups were in Hardy-Weinberg equilibrium, and were not influenced by gender or age (Table 2).

Autophagy was considered as a novel and promising pathway that can be used as a target for development of better vaccines and new drugs designed to eliminate Mtb, but recent studies have brought that hypothesis into question (2). One particularly powerful approach to assess the role of certain processes for anti-tuberculosis host defence in humans is to investigate whether genetic variation in genes involved in that pathway influence susceptibility to infection. Among the ATG family of genes, ATG5 is an important modulator of the autophagy process charged with the expansion and closure of the double stranded structure called autophago- 


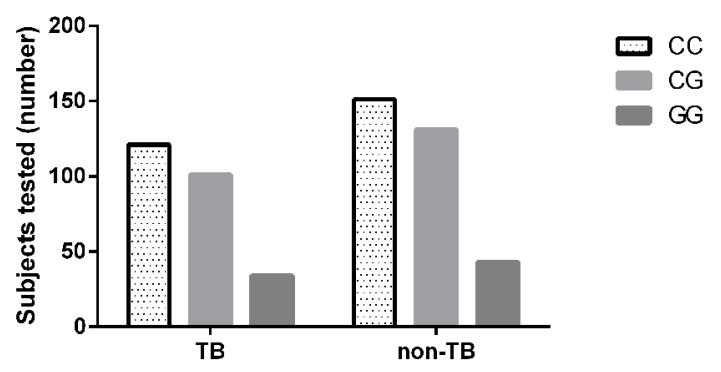

Figure 1. Frequency of ATG5 rs2245214 (c.574- 12777G $>$ C) polymorphism

some. There are both in-vivo and in-vitro studies focused on autophagy and more specifically ATG5 gene and its involvement in tuberculosis. Different studies render different results for the in-vivo approach, thus there is either a modest deficiency in macrophage control following infection in mouse strains which lack ATG5 in myeloid cells, or a severe one that leads to a higher level of bacteria and faster death. All these findings point out that autophagy and ATG5 gene are essential for in vivo Mtb control. However, no clear conclusions regarding the role of genetic polymorphisms in ATG5 gene could be drawn, with some studies suggesting an impact on the susceptibility to TB, while not being able to reproduce that. In the present study we aimed to investigate this hypothesis in a Romanian cohort with tuberculosis: no influence on susceptibility to infection could be observed.

Furthermore, little is known regarding susceptibility to tuberculosis in individuals carrying genetic variants in the NOD2 gene. The potential role played by the NOD2 gene in TB infection was suggested by two studies that revealed the involvement of this gene in recognition of Mtb through signalling the production of proinflamatory cytokines. Recent studies showed that NOD2 signaling can initiate the autophagy response sequestrating the intracellular bacteria in

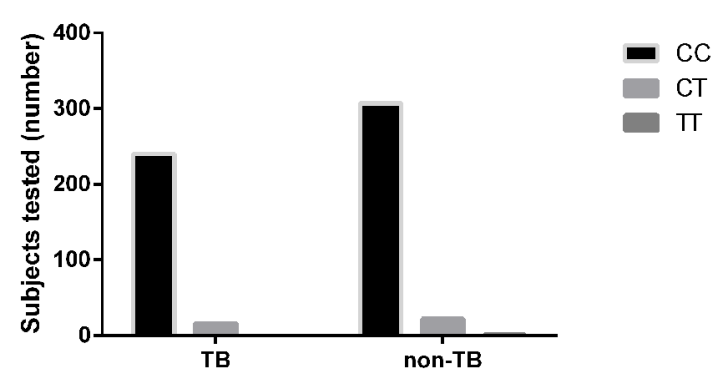

Figure 2. Frequency of NOD2 rs2066844 (c.2104C $>$ T) polymorphism

the autophagosome and limiting the infection. NOD2 rs2066844 SNP was associated in multiple studies with susceptibility to other chronic pathological conditions such as Crohn's disease, schizophrenia and asthma. However, we were not able to identify any association between NOD2 rs2066844 (c.2104C>T) polymorphism and the increased risk to develop active TB. This observation, coupled with absence of effects of ATG5 genetic variants, suggest that autophagy and Mtb have a complex interaction, and that the autophagy process may be redundant for host defense against tuberculosis, as recently suggested (2).

One limitation of the current study is represented by the size of the cohorts, which may not have been sufficient to exclude a role for ATG5 and NOD2 in TB. In addition, our study was underpowered to assess the influence of ATG5 and NOD2 genotypes on the severity of the disease. We acknowledge the possible bias the lack of latency status for the control group may introduce. Though, progress from TB infection to clinically active case is complex and introducing latency into our model is debatable in improving the analysis of susceptibility to active pulmonary $\mathrm{TB}$, especially given the sample size.

In conclusion, this is the first study to assess the role of polymorphisms in autophagy genes in 
an Eastern-European population with a very high burden of tuberculosis, and these results suggest that the ATG5 and NOD2 genotypes are not related to the risk for developing active TB. In addition, we found no evidence of an interaction between ATG5 rs2245214 and NOD2 rs2066844 variant genotypes. The lack of association between ATG5 rs2245214 and NOD2 rs2066844 and susceptibility to TB revealed by this study does not exclude the possibility that other SNPs in the two genes (or other autophagy genes) could contribute to the risk of developing active TB.

\section{Acknowledgements}

The research leading to these results has received funding from the project 217EU/2013, Module III of the national CAPACITIES Programme, a support scheme for Romanian participation to EU-FP7.

M. Ioana was supported by a research grant "Vitamin D deficiency and immunogenetic factors in relation to Tuberculosis (RID-TB)" through UEFISCDI-Young Research Teams, PN-II-RU-TE, 163/01/10/ 2015.

M.G.C was supported by the project "Excellence program for multidisciplinary doctoral and postdoctoral research in chronic diseases", Grant POSDRU/159/1.5/S/133377, supported by the Sectoral Operational Program Human Resources Development 2007-2013, financed from the European Social Fund.

Conflict of interest: No conflict of interest to declare.

\section{References}

1. WHO-Global tuberculosis report 2015. WHO/HTM/ TB/2015.22.

2. Kimmey JM, Huynh JP, Weiss LA, Park S, Kambal A, Debnath J, et al. Unique role for ATG5 in neutrophil-mediated immunopathology during M. tuberculosis infection. Nature. 2015;528(7583):565-9. DOI: 10.1038 /nature16451.
3. Bento CF, Empadinhas N, Mendes V. Autophagy in the fight against tuberculosis. DNA and cell biology. 2015;34(4):228-42. DOI: 10.1089/dna.2014.2745.

4. Levine B, Mizushima N, Virgin HW. Autophagy in immunity and inflammation. Nature. 2011;469(7330):32335. DOI: $10.1038 /$ nature 09782 .

5. Xie Z, Klionsky DJ. Autophagosome formation: core machinery and adaptations. Nature cell biology. 2007;9(10):1102-9. DOI: 10.1038/ncb1007-1102.

6. Deretic V, Levine B. Autophagy, immunity, and microbial adaptations. Cell host \& microbe. 2009;5(6):52749. DOI: 10.1016/j.chom.2009.05.016.

7. Suzuki K, Ohsumi Y. Molecular machinery of autophagosome formation in yeast, Saccharomyces cerevisiae. FEBS letters. 2007;581(11):2156-61. DOI: 10.1016/j. febslet.2007.01.096.

8. Youle RJ, Narendra DP. Mechanisms of mitophagy. Nature reviews Molecular cell biology. 2011;12(1):914. DOI: $10.1038 / \mathrm{nrm} 3028$.

9. Klionsky DJ. Autophagy: from phenomenology to molecular understanding in less than a decade. Nature reviews Molecular cell biology. 2007;8(11):931-7. DOI: $10.1038 / \mathrm{nrm} 2245$.

10. Kuma A, Hatano M, Matsui M, Yamamoto A, Nakaya H, Yoshimori $\mathrm{T}$, et al. The role of autophagy during the early neonatal starvation period. Nature. 2004;432(7020):1032-6. DOI: 10.1038/nature03029.

11. Gutierrez O, Pipaon C, Inohara N, Fontalba A, Ogura Y, Prosper F, et al. Induction of Nod2 in myelomonocytic and intestinal epithelial cells via nuclear factor- $\kappa \mathrm{B}$ activation. Journal of Biological Chemistry. 2002;277(44):41701-5. DOI: $10.1074 / \mathrm{jbc}$. M206473200.

12. Girardin SE, Boneca IG, Viala J, Chamaillard M, Labigne A, Thomas G, et al. Nod2 is a general sensor of peptidoglycan through muramyl dipeptide (MDP) detection. Journal of Biological Chemistry. 2003;278(11):8869-72. DOI: 10.1074/jbc. C200651200.

13. Inohara N, Ogura Y, Fontalba A, Gutierrez O, Pons F, Crespo J, et al. Host Recognition of Bacterial Muramyl Dipeptide Mediated through NOD2 IMPLICATIONS FOR CROHN' S DISEASE. Journal of Biological Chemistry. 2003;278(8):5509-12. DOI: $10.1074 / \mathrm{jbc}$. C200673200. 
14. Travassos LH, Carneiro LA, Ramjeet M, Hussey S, Kim Y-G, Magalhães JG, et al. Nod1 and Nod2 direct autophagy by recruiting ATG16L1 to the plasma membrane at the site of bacterial entry. Nature immunology. 2010;11(1):55-62. DOI: 10.1038/ni.1823.

15. Ferwerda G, Girardin SE, Kullberg B-J, Le Bourhis L, De Jong DJ, Langenberg DM, et al. NOD2 and tolllike receptors are nonredundant recognition systems of Mycobacterium tuberculosis. 2005.

16. CUCU MG, RIZA AL, CIMPOERU AL, STREATA I, SOSOI SS, CIONTEA MS, et al. Implication of TLR2 polymorphism in pulmonary tuberculosis. Annals of the Romanian Society for Cell Biology 2015;20 (1).

17. Liu PT, Stenger S, Tang DH, Modlin RL. Cutting edge: vitamin D-mediated human antimicrobial activity against Mycobacterium tuberculosis is dependent on the induction of cathelicidin. The Journal of Immunology. 2007;179(4):2060-3. DOI: 10.4049/jimmunol.179.4.2060.

18. Fabri M, Stenger S, Shin D-M, Yuk J-M, Liu PT, Realegeno S, et al. Vitamin D is required for IFN- $\gamma-$ mediated antimicrobial activity of human macrophages. Science translational medicine. 2011;3(104):104ra2ra2.

19. Jounai N, Kobiyama K, Shiina M, Ogata K, Ishii KJ, Takeshita F. NLRP4 negatively regulates autophagic processes through an association with beclin1. The Journal of immunology. 2011;186(3):1646-55. DOI: 10.4049/jimmunol.1001654.

20. Saitoh T, Akira S. Regulation of innate immune responses by autophagy-related proteins. The Journal of cell biology. 2010;189(6):925-35. DOI: 10.1083/ jcb.201002021.

21. Mizushima N, Levine B, Cuervo AM, Klionsky DJ. Autophagy fights disease through cellular self-digestion. Nature. 2008;451(7182):1069-75. DOI: 10.1038/ nature 06639 .

22. Castillo EF, Dekonenko A, Arko-Mensah J, Mandell MA, Dupont N, Jiang S, et al. Autophagy protects against active tuberculosis by suppressing bacterial burden and inflammation. Proceedings of the National Academy of Sciences. 2012;109(46):E3168-E76. DOI: 10.1073/pnas. 1210500109 .

23. Watson RO, Manzanillo PS, Cox JS. Extracellular M. tuberculosis DNA targets bacteria for autophagy by activating the host DNA-sensing pathway. Cell. 2012;150(4):803-15. DOI: 10.1016/j.cell.2012.06.040.
24. Songane M, Kleinnijenhuis J, Alisjahbana B, Sahiratmadja E, Parwati I, Oosting $M$, et al. Polymorphisms in autophagy genes and susceptibility to tuberculosis. PloS one. 2012;7(8):e41618. DOI: 10.1371/journal.pone.0041618.

25. Cooney R, Baker J, Brain O, Danis B, Pichulik T, Allan $P$, et al. NOD2 stimulation induces autophagy in dendritic cells influencing bacterial handling and antigen presentation. Nature medicine. 2010;16(1):90-7. DOI: 10.1038/nm.2069.

26. Homer CR, Richmond AL, Rebert NA, Achkar JP, McDonald C. ATG16L1 and NOD2 interact in an autophagy-dependent antibacterial pathway implicated in Crohn's disease pathogenesis. Gastroenterology. 2010;139(5):1630-41. e2.

27. Hugot J-P, Chamaillard M, Zouali H, Lesage S, Cézard J-P, Belaiche J, et al. Association of NOD2 leucine-rich repeat variants with susceptibility to Crohn's disease. Nature. 2001;411(6837):599-603. DOI: 10.1038/35079107.

28. Ogura Y, Bonen DK, Inohara N, Nicolae DL, Chen FF, Ramos R, et al. A frameshift mutation in NOD2 associated with susceptibility to Crohn's disease. Nature. 2001;411(6837):603-6. DOI: 10.1038/35079114.

29. Economou M, Trikalinos TA, Loizou KT, Tsianos EV, Ioannidis JP. Differential effects of NOD2 variants on Crohn's disease risk and phenotype in diverse populations: a metaanalysis. The American journal of gastroenterology. 2004;99(12):2393-404. DOI: 10.1111/j.1572-0241.2004.40304.x.

30. Kanaan ZM, Eichenberger MR, Ahmad S, Weller C, Roberts H, Pan J, et al. Clinical predictors of inflammatory bowel disease in a genetically well-defined Caucasian population. Journal of negative results in biomedicine. 2012;11:7. DOI: 10.1186/1477-5751-11-7.

31. van Schijndel JE, van Loo KM, vanZweeden M, Djurovic $\mathrm{S}$, Andreassen OA, Hansen T, et al. Three-cohort targeted gene screening reveals a non-synonymous TRKA polymorphism associated with schizophrenia. Journal of psychiatric research. 2009;43(15):1195-9. DOI: 10.1016/j.jpsychires.2009.04.006.

32. Kabesch M, Peters W, Carr D, Leupold W, Weiland SK, von Mutius E. Association between polymorphisms in caspase recruitment domain containing protein 15 and allergy in two German populations. Journal of allergy and clinical immunology. 2003;111(4):813-7. DOI: 10.1067/mai.2003.1336. 